\title{
Othello and the Perception of Race within the Cultural Context of Czech and Slovak Theatres
}

Zuzana Koblišková

\begin{abstract}
This study in its current form has been inspired by the keynote lecture of Dr Christian M. Billing at the Brno Theatralia Conference in 2016 analysing two productions of Othello, one of them being the production of 2014 at the National Theatre Brno. He questioned the way scenography could raise issues of race and identity using common material signifiers such as props, costumes or theatre make-up. The presented study proposes a polemic with his conclusions based on an overview of the productions of Othello within the Czechoslovak context and suggests Czech and Slovak critics should pay more attention to the issues of race and identity with regards to productions of Othello.
\end{abstract}

\section{Keywords}

Othello, race, Negro, animal, evil 
Initially, I had prepared an analysis of three productions under the direction of Rastislav Ballek and costume design by Katarína Holková, a specific collaboration of two Slovak theatre professionals also working in Moravian theatres. I was analysing the style of the costumes, Holkovás approach to costume design through fashion design and appropriation of costumes to the stage design creating powerful visuals in context with the plays. That would have been a very superficial analysis, however, due to a fascinating cultural clash, I did not deliver my speech at the conference the way I intended, and I would also like to adjust my written paper with regards to the situation that occurred at the Brno Theatralia Conference 2016. Christian Billing had delivered a keynote speech analysing two productions of Othello, one of them being the production of 2014 Othello at the National Theatre Brno. He questioned the way scenography could raise issues of race and identity using common material signifiers such as props, costumes or theatre make-up. The thorough analyses lead to an astonishing conclusion, at least for me: 'Ballek's production presented racism in all its ugly horror' (BILLING 2016). How have I missed it? I have seen the production several times and have read all the reviews. I have had a chance to discuss the production with the director; the interpreter of the character of Othello, Róbert Roth, and the costume designer, Katarína Holková, at several public discussions and in private. The issue of racism against black Africans has never occurred to me as the central theme of the production. Therefore, my present study is an attempt to identify the reasons why the production hasn't raised the questions of racism within the community of Czech and Slovak academics as it has for a British scholar.

Are we, Czechs and Slovaks, less sensitive to the issues of racism towards black Africans? Was Ballek's interpretation supporting the 'presumptions of a seemingly dark and evil essential truth about black African barbarity' (BILLING 2016)? How have we, Czech and Slovak nationals, missed or perhaps even ignored the racist context beyond the transformation of Othello into a beast? Or more importantly, why have we overseen it and not talked about it enough?

C. M. Billing has provided a broader pan-historical and intercultural context of artistic representation of the issue of racism based on the black colour of skin in theatre. C. M. Billing explained the history and the political background of the word 'negritude' and the reasons why he chose to use it. I am using it because I have struggled with choosing the appropriate expressions to use within our cultural context. The expression 'negritude' does not have an appropriate translation into the Slovak language. We use an expression 'niger' which is a very offensive imported expression. If we talk about race, the expression is 'černoch' and that is a neutral expression that does not have any negative connotation by itself. On the other hand, the expression 'čierny' or 'black' can be easily used interchangeably for a 'black African' as well as for a 'Gypsy' within our environment and always has a negative connotation. To differentiate these cultural aspects, I will be using the expressions 'black African', 'Gypsy' and 'Roma' (with deliberate racial connotation) to explain the period contexts more clearly.

I intend to offer a comprehensive framework of staging Othello within an environment where black coloured skin is so scarce that not only it is close to impossible to 


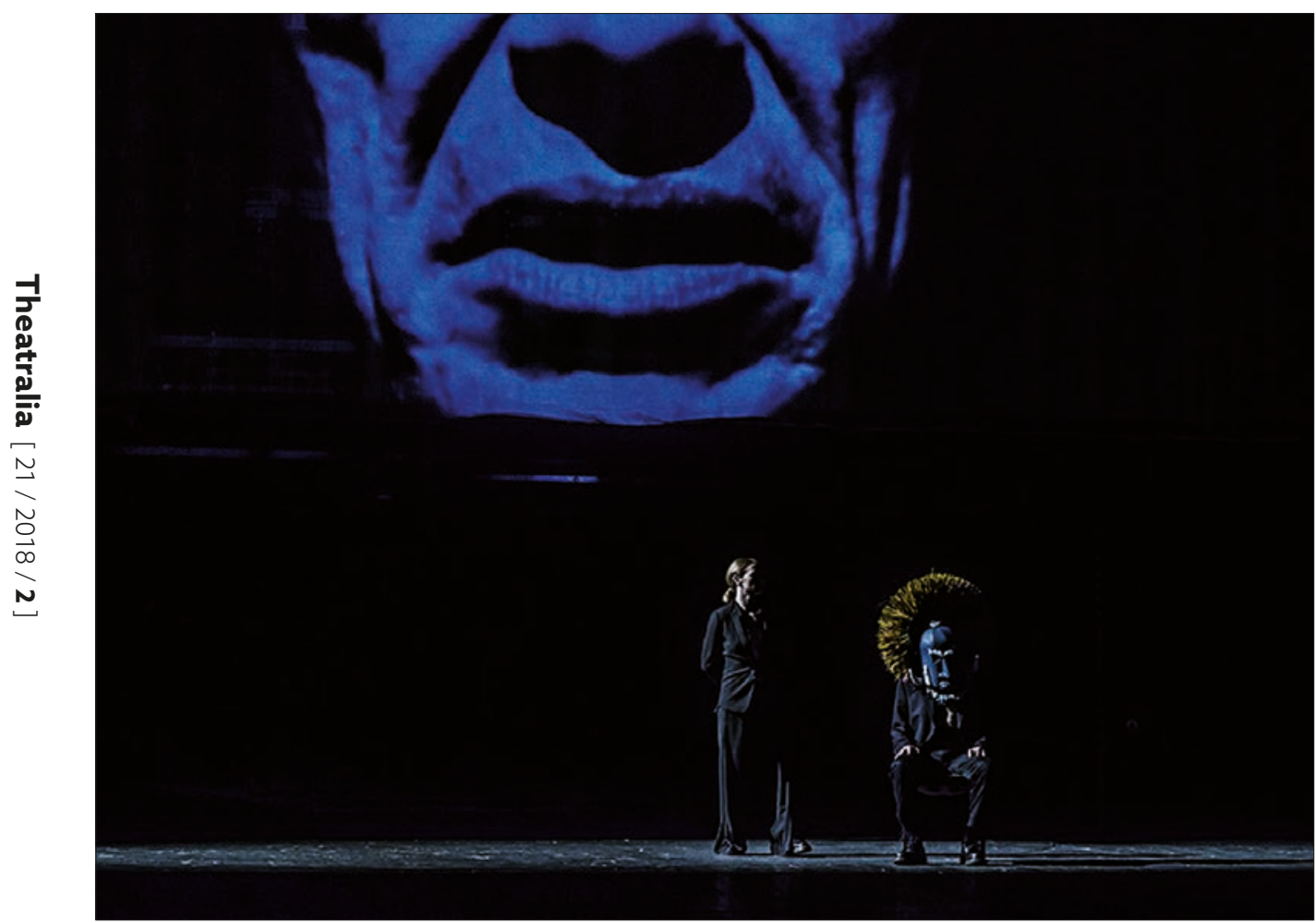

Fig. 1: Othello, National Theatre Brno, direction: Rastislav Ballek, costume design: Katarína Holková, stage design: Jozef Ciller. foto: Kiva.

find a black African actor to play Othello, some people in our countries have seen black African people only on TV. In fact, there has been only one black African actor in the history of the Slovak theatre - Ibrahim Maiga. ${ }^{1}$ He was also a singer and a comedian, and therefore despite his original skin colour, no one would cast him to play Othello, as the audience would think of him as the 'black shepherd' from his single in which he mocks his skin colour juxtaposed against the whiteness of the Slovak traditional mountain landscape. The same problem was expressed by Daniel Špinar when directing Othello for the National Theatre in Prague in 2014. 'Casting a real black African for Othello has become a strong tradition in Great Britain. It is the clearest and most comprehensive solution and all the subconscious elements of the drama work without further explanations... But try to find an actor in the Czech Republic with black skin colour that could deliver right away Shakespeare's blank verse on the

1 Ibrahim Maiga (1963) - a singer, actor and entertainer. He was born in Mali, he moved to Czechoslovakia in the 1980s to study at the Technical University in Bratislava. He dropped out of school and built his career as a singer and actor. He is now a Slovak citizen and is regarded a Slovak actor and singer. His most famous song is called 'Čierny bača' [Black Shepherd] in which he made fun of himself being a black African wearing a Slovak traditional folk costume of shepherds. He has never learned the Slovak language properly but he owned the way he distorted it and made it his signature feature. The key to his success was that he mocked and made a self-parody of his difference and his skin colour. 
stage in perfect Czech' (ŠPINAR 2014). He further explained the so-called 'black undervests' tradition, used in Czech theatres, which leaves the audience in Czech theatres within their comfort zone: 'Czech spectators always agree with this convention quite easily, and then they just observe from the auditorium a white actor diligently imitating a black African' (ŠPINAR 2014). C. M. Billing postulated that there is a way of reading Othello as a play in which the 'noble' moor suffers a breakdown caused by jealousy, and also by the racist presuppositions of the society. The main argument C. M. Billing proposed about Ballek's Othello was that when a black actor plays Othello, it is easier, or we have adapted to reading the racist context more carefully, but we are also aware of the personal tragedy aspect of the play. He also suggested that the 'in-your-face vulgarity' of the production emphasised the transformation of a white man into a black man. That was illustrated by adding props to Roth's costume placing him in several disparate countries in the continent of Africa if analysed in detail, as C. M. Billing undertook in his paper. According to him, Othello was stripped of the Western trappings, and he reverted to an image or a representation of typical prejudice of the spectators.

I do agree with C. M. Billing, that although the widespread practice in Anglo-American theatres has for some decades already been that a black African actor should play Othello, it is not the only way in which this play can work in a politically correct manner. Speaking about political correctness, Mark Leiren-Young, a Canadian playwright, wrote a monodrama dealing with the issue of political correctness in theatre and he used one of Shakespeare's characters as the frame for his monodrama. According to Gaetan Charlebois in The Canadian Theatre Encyclopedia the play Shylock is 'a wondrous diatribe about art, the responsibilities of the artist, and about whether theatre exists to make people comfortable' (CHARLEBOIS 1993, quoted from Biz Books @2016). The character in the play, the actor called John, is a Jew and he played Shylock in a theatre production that was cancelled due to its controversy. John decided to defend the play after the finale, and he questioned the political correctness of theatre productions nowadays. A very similar argumentation appeared in the play as was presented by C. M. Billing at the conference. C. M. Billing contemplated whether the racist aspects would be more apparent in our cultural context if a Roma actor had played Othello. Mark Leiren-Young also questioned how the prejudice would have changed if The Merchant of Venice was situated in Israel and Shylock was Palestinian and not Jew. Furthermore, he questioned whether the goal of all the productions in the present should be interpreted only in positive and politically correct manner if the interpretation should always follow the presentism theory that calls upon awareness of the current gender and race policies. However, if the plays did not raise controversy and were all corrected (or censored) into more 'digestible' versions, could they still be considered art?

Half of the productions of Othello in Slovak theatres were premiered before 1978, and the first one at the Slovak National Theatre was the one in 1978. Until then, the well-established practice of make-up masking the actors into a black African was employed the same way as at most of the theatres within the mainly white-skinned population. The so-called 'shoebox' or 'black sweatshirts' practice of actors playing Othello 
wearing black make-up remained in place in Czech and Slovak theatres well into the 1980s. I will not consider those productions at the moment, as I would like to concentrate on several productions that have used different approaches and tackled the issue of racism, perhaps in a more locally appropriate way.

There was a twenty-six-year gap after the production in 1978, and the seven more recent productions staged after 2004 have gone beyond the previous make-up tradition and did not pay immediate attention to the skin colour of the actors playing Othello. The last production for the Summer Shakespeare Festival in $2016^{2}$ had a white actor as Othello (Jozef Vajda), and it was stripped down to a very minimalist stage and costume design approach. The 'darkness' of the skin was manifested by the black coats and costumes of all the characters except for Desdemona who wore a red dress with a floral motif. The production focused on age. It was Othello's fear of losing Desdemona due to the age difference rather than his race that made him so jealous and capable of killing. This production ignored or overcame the issue of the race by narrating a story of an insecure old man, although the word Moor remained in the text.

The first professional production of Othello in Slovakia that did not use the 'shoebox' makeup tradition was in 2005 in Košice. Unfortunately, according to the reviews, the director failed to tackle the issue of race adequately. Othello blended in with others, and his racial difference was, in fact, ignored. Oleg Dlouhý, a theatre critic and historian, commented: 'Othello is no different than others wearing only trousers with some reminiscence to an Arabic costume and without make-up that would make him look like a black African or at least Moor. It is quite challenging to find a clear concept of the whole production' (DLOUHÝ 2005: 22). On the other hand, Dlouhý looked for a traditional reading of the play, in which Othello is supposed to be different from the Venetians. Therefore, he might have overlooked the fact that the creators deliberately wanted Othello to blend in to emphasise that despite his origin, he was no different to the other characters when it came to matters of jealousy and violence.

In 2007, theatre ASTORKA Korzo '90 brought about an interpretation of Othello that was more sophisticated in its scenographic and sartorial representation. Zuzana Bakošová-Hlavenková has referred to it as a 'black and white' Othello (BAKOŠOVÁHLAVENKOVÁ 2008). The director, Juraj Nvota, decided to concentrate on the horrors of manipulation and jealousy. The costume representation was simple, the villains were in contemporary black costumes, and the good characters were in white. However, Othello wore white at the beginning, and his change of character was illustrated only in a slight colour change of his costume into beige and a black mask after the murder of Desdemona. Emilia wore red, as in Nvota's interpretation she was 'experienced, cynical, sure about the corruption of the world' (BAKOŠOVÁ-HLAVENKOVÁ 2008). Emilia was a seductress, and she considered cheating normal.

On the other hand, Desdemona, wearing a white dress and a white wig represented pure naiveté. The colour representation of good versus evil and red as a typical colour of sexual desire, betrayal and cheating is widespread and does not have to immediately

2 Direction: Michal Vajdička, stage design: Pavol Andraško, costume design: Katarína Hollá. 
raise the issues of race, although the subliminal connection will always remain. The scenographic solution was straightforward, Tomáš Rusín used several panels with window blinds all in natural wood and a T-shaped stage that extended into the auditorium. Although the idea behind it referred to the meaning of the expression 'jalousie', French for jealousy, hatred and the third meaning is window blinds. They allowed characters to see through them, hide behind them or eavesdrop, facilitating the intrigues and pushing forward a false agenda. Most of the emotionally powered scenes were performed at the extension of the stage right among the people sitting in the auditorium.

Until now it may have seemed that Slovak theatre creators have been entirely ignorant of the racial issues connected to this Shakespeare play. It is as if the tradition shifted from the artificially 'blackened' Othellos to Othellos that are white and just jealous and cruel in the same way as any other men of any race. After C. M. Billing's keynote at the Brno Conference, a suggestion was brought up as to whether those of us who defended the production would have been of the same opinion if Roth had been made to look like a Gypsy. I guess the case would have been similar as if in England today someone would paint a white actor with black make-up and made him represent a black African. The idea of appropriating Othello into our cultural environment by making him a Roma or Gypsy is perhaps the most comparable. The prejudice the Czechs and Slovaks have against black Africans is mostly 'second hand', whereas the prejudice against Roma people is 'first hand' and it remains a pressing issue today.

Moreover, we have a political party in the Slovak Parliament that is openly racist against Roma people and Muslims. ${ }^{3}$ The issue of racism against Muslims has been raised by the production of a musical called Iago (based on Shakespeare's Othello) in 2016 at the New Stage of the Slovak National Theatre. Despite the original idea of tackling this pressing issue, according to the reviewer Karol Mišovic, the creators have failed to address the issue to its full potential.

The contrast between Christianity and Islam is currently a frequent topic, but the musical lacks a comprehensive interpretive key to the motivation of the creators except for some melodies and remarks on Allah. The relationships and motivations of the characters remained the same as in Shakespeare's original but the transfer to a different epoch, continent and religious community has not enriched the story significantly. (MIŠOVIC 2016)

In 2010, the director of the Arena Theatre, Juraj Kukura, invited a Czech director Jiří Pokorný to stage Othello in Bratislava in an unconventional way as a Roma. Pokorný pitied the actors playing Othello in the past, who had to be painted black to represent Moor or black African and therefore the idea of a real Roma actor playing Othello inspired him.

In the beginning, Alexandra Grusková, the costume designer, dressed everybody in contemporary army uniforms. As the conflict evolved, the costumes changed into the

3 Their policy is similar to the white supremacist organizations in the USA. They are also against black African people but as there are not too many of them in Slovakia they do not need to press the issue forward as much. 


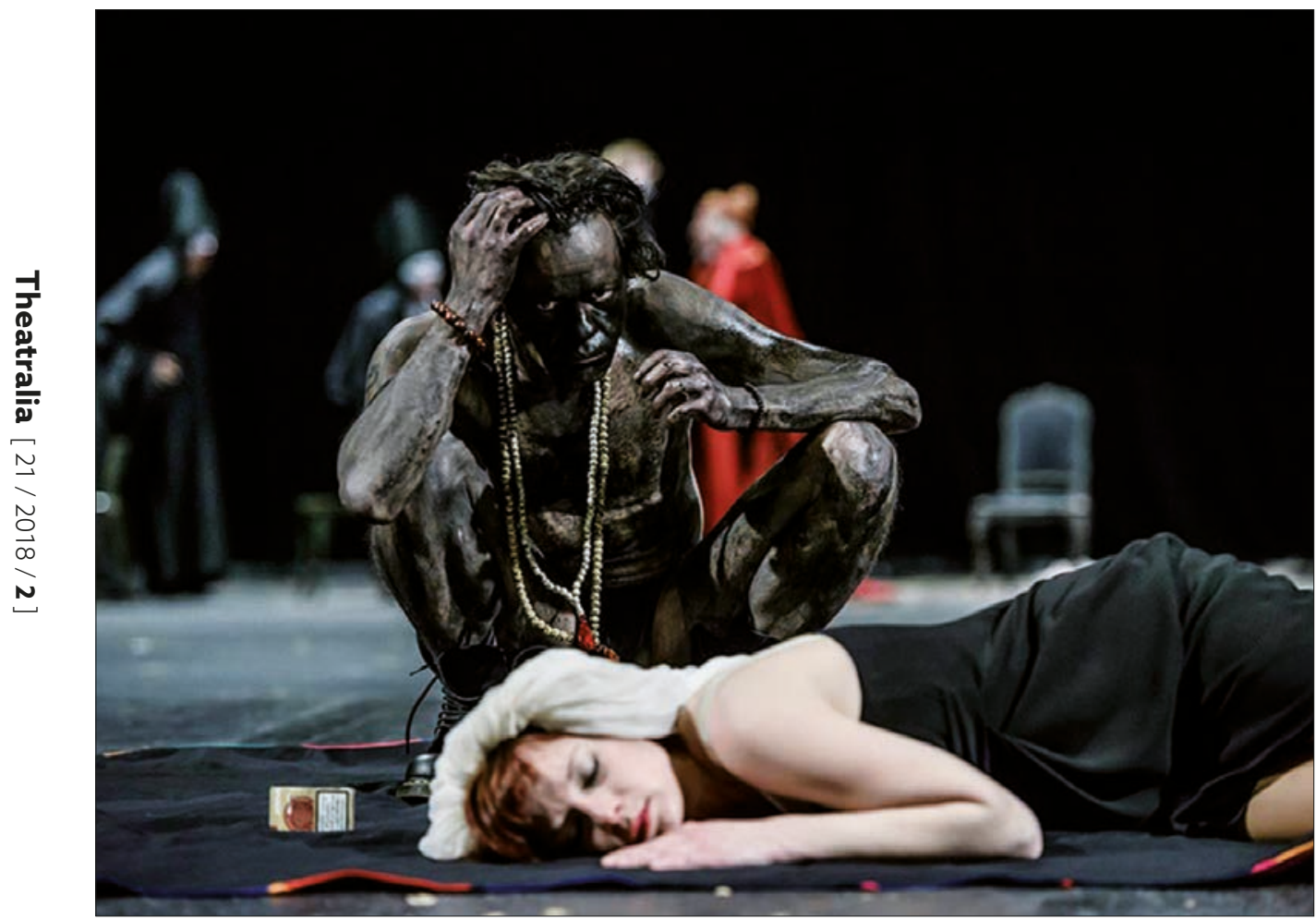

Fig. 2: Othello, National Theatre Brno, direction: Rastislav Ballek, costume design: Katarína Holková, stage design: Jozef Ciller. foto: Kiva.

stereotypical clothing of the Gypsy mafia. The so-called 'Roma question' or even less politically correct 'The Gypsy problem' was repeatedly brought up by all the characters. Specific cultural referents were implemented to make the issue local and familiar to the audience. Karol Csino as Othello was sent back to Lunik IX or even to Letanovce, areas with high criminality, horrible living conditions infamously known for the high concentration of Roma people. Such notions are incredibly racist, and the fact that Csino is of Roma origin makes it even worse as it was hard to pretend that it was just a role he played, and such remarks activate the prejudice in people who are prone to it. By this I mean that if there was a racist person in the audience or at least a person who had previously had a negative experience with a Roma person, he or she would be more likely to have their prejudice against Roma people reinforced by such interpretation as they would if the actor was not of the race and only played the role of a Roma. If a non-Gypsy actor plays the character, it may always be taken as exaggerated, or with some reserves, maybe even with the belief that it cannot be as bad in reality.

On the other hand, the authenticity of a Roma actor makes the expressions more believable. Milan Polák, a theatre critic, summarised the racial issue of the production as follows: 
The fact that the actor did not have to wear make-up to create a believable impression of a Venetian Moor was interesting as it was in a way a shift of the story into the present representation of the eternal conflict of good versus evil. The problem is when the Roma problem or the Gypsy problem as it is referred to in the production (as the expression Gypsy is the most frequent in the production), becomes the dominant issue and covers up the inner sense of the drama of human relations. It is not possible to implant the conflict of an innocent soul born to be kind, truthful and honest yet changed by evil, deceitfulness and brittleness, superficially into an environment of Lunik IX and Letanovce full of passionate Gypsies in colourful shorts and shirts with floral motives wearing barefoot sandals and running wild. (POLÁK 2010: 13)

Having seen the production, I must admit the issue of racial discrimination was much more evident for me than in Ballek's Othello. The heavy metal music composed by Václav Noid Bárta changed into the sad violin melodies of Gypsy music as Othello undressed from his black army uniform wearing khaki shorts and a shirt with a floral motif with a large golden chain. Csino's costume in the second half of the production was a typical representation of the so-called 'golden chain mafia Gypsy'. Iago followed Othello and took off his uniform wearing similar clothes as Othello. On the other hand, Desdemona changed from a white simple long dress into a pink and purple pompous festive dress. Csino manifested Othello's gradual transformation by jealousy through expressively acting out a drunk and violent man with rapist tendencies. He performed indications of rape on Desdemona as well as Emilia several times. Such representation conforms to all the stereotypical beliefs, and, unfortunately, only made the audience laugh. Instead of using the presence of a Roma actor to suppress such beliefs and create the narrative about how, despite his racial difference, his jealousy comes from the human nature we all share across the races.

Gabriela Marcinková as Desdemona sang a song about a wounded birch tree based on a classic Slovak poem by Mária Rázusová Martáková instead of the original Willow Song. The song is to prepare her for death and to highlight her innocence. A sad violin melody accompanied Othello's soliloquy above the sleeping Desdemona. Desdemona lay on the floor lit from the above forming a circle around her. Her white lingerie and her pale skin almost blended with the white floor. Othello wore a white shirt and a casual black suit as if he was a more decent mafia member. His appearance, although still typical for the Roma mafia environment, was not so laughable anymore. He was serious about the murder he was about to commit, even though just a minute ago he appeared to be drunk and in a jealous rage. At the moment when the act of the murder began, the projection on the stage changed into a large wooden ornamental frame which made the scene almost sacred and surreal at the same time. It was as if the director was trying to evoke a murder scene on a baroque painting, perhaps referring to the stereotypes of wealthy mafia Romas having their houses decorated with distasteful and often fake antique furniture. Csino's Othello choked Desdemona for 50 seconds, and the brutality was comparable with Ballek's Othello in Brno, although Roth's Othello was torturing his Desdemona for twice as long. 
Although this production had the potential to raise principal issues of race and was even funded directly by the Slovak Ministry of Culture, therefore its purpose was also educative and supposedly anti-racist, Csino was criticised for not being able to deliver the heroic dimension of his Othello. For me, Csino's interpretation was a first-hand validation of the widespread prejudice I have been brought up with. The production did not last long in the repertoire and unfortunately had not raised the awareness it could have. As one of my colleagues told me, 'Everybody just wants to forget the production'. The reviewers all commented on the race of the main character, regarded it as unconventional but did not bother to further analyse the issue in the context of the 'Gypsy problem' we have been tackling in Slovakia for decades. The stereotypes were only supported if not strengthened. The last sentence that Emilia cried out 'The Gypsy killed one of ours' sums it all up as it evokes a stereotypical expression of Romas when talking about members of their families/race ('one of ours'). As such it seems the racism was meant to be in-your-face but whether the motive was mockery or it was meant to endorse the racism, it is hard to say. Maybe we should really forget such shallow and racist interpretations of Othello and try to find a way to tackle the issue of race that this play offers within our cultural context in a way that the play deserves.

Before I proceed to Ballek's production, there is one more production I need to mention. Daniel Špinar directed a production of Othello at the National Theatre in Prague in 2014 that had a clown in it who interrupted the play only to recite racist jokes for no apparent reason or connection to what was happening on the stage. Špinar admitted that he intended to provoke the audience with that element of the production, but he failed to contextualise the character of the clown and draw some moral out of such interruptions. His Othello was a wild animal tamer and was accompanied by plastic almost life-like tiger on the stage. He had tiger pattern tattoos all over his arms, shoulders and neck. Having tattoos is not unique anymore, and there are so many people with tattoos today that it is no longer a symbol that would stand out as much. In the Czech Republic, there was even a presidential candidate in 2013 covered in tattoos head to toe, and in fact, Špinar might have referred to Vladimír Franz by that visual detail. His Othello was white, and, besides the tattoos, he was no different than other characters. It was the clown who was supposed to bring about the issue of race. Unfortunately, the clown seemed very inadequate. Although the overall appearance of the scenography and costumes was also promising, the production at the National Theatre in Prague ended up being as superficial as the production at the Arena Theatre in Bratislava, and both failed in delivering the message they set out to bring by provocative and unconventional interpretations.

The National Theatre in Brno, on the contrary, invited a Slovak director, a Slovak costume designer (Katarína Holková), a Slovak stage designer (Jozef Ciller), and a Slovak Othello (Róbert Roth) to stage Othello in Brno. Róbert Roth as Othello spoke several languages (Czech, Slovak, English, and even Zulu). He was as white as a Slovak man can be, and he ended up covered in paint like most of the Slovak actors playing Othello had until the late 1970s. However, the intention of Ballek was not to make this 
step backwards and suggest Roth was to transform into a black African man. Theatre Critic Tereza Frýbertová even suggested that 'the creators have diverted from the possible topic of racism and focused on the topic of the general difference in the widest context' (FRÝBERTOVÁ 2014) by not painting Roth's skin black from the beginning, therefore not suggesting he was of African descent. Roth explained his character as having been taken out of his culture and put into a different environment where he would not have had to deal with such problems. According to Roth, Othello did not know what to do with the jealousy he felt, and that is why he returned to his roots, the true nature of all the people - he became a savage primate. ${ }^{4}$

Emilia's dress was neutrally black throughout the whole production with only slight, insignificant changes. Her character was stable with her values, she has not undergone any moral transformation as Othello, and that is why her costume did not need to change. Besides the neutral black suits, there were also khaki uniforms used to set the whole ensemble in a military environment and serving that way the original Shakespeare's idea of evolving the story around such environment. The majority of the characters, including Desdemona, were wearing army boots as a uniting costume visual detail.

Robért Roth is considered one of the most highly regarded Slovak actors of the younger generation. His skin tone is fair, almost translucent. Playing Othello, he started off in a white uniform decorated with honours. C. M. Billing pointed out in his keynote that there might have been some allusions to African military and political leaders, such as Libyan Muammar Gaddafi. Even though Holková was not trying to create a specific illusion to an African leader who could or should have been identified by the audience, the question is, how responsible or irresponsible of the costume designer it is to actually create a costume not admitting the possibility of someone reading into it to such extent as to making connections with specific dictators and allowing context into the play that was not meant for it.

Othello's modern lustrous and neat uniform should have emphasised his good characteristics, and Holková chose the white colour to create an opposite pole to his darker bestial change later on. He began the story as a hero who made a white girl, coming from a good background, fall in love with him based on the heroic stories of his life. According to Ballek's interpretation in the Brno production, Othello ended his life as a wild cannibalistic native tribe member looking more like a beast than like a human being. Othello's costumes changed throughout the production as he was becoming more and more beast-like. From a soldier through a phase in which he was becoming a predator [suspecting the betrayal of his wife] wearing a shirt with a cheetah pattern, to a black suit with no shirt at all to a black painted skin 'costume'. All his costume changes took place right on the stage, and an attentive spectator could have noticed them. Roth covered his body with a mixture of skin paint and mud of dark colour which made him look like a native tribe member preparing for some

4 Shakespeare in Dialogue, a seminar organised by the Department of Audio-visual Theatre Art at the Academy of Performing Arts in Bratislava, 5.-6. 12. 2016. R. Roth was one of the speakers. 
ritual rather than as a black African Moor. The corals he was wearing as part of the tribal costume were his contribution to the outfit. Holková originally had an even more tribal-like costume in her mind, however referring to a cannibal in general. According to the very detailed analysis of C. M. Billing, Othello must have travelled all around Africa as the accessories, and stage props he used throughout the performance had various places of origin, some of them as far as five thousand kilometres apart. In this case, the creators did not pay attention to such details and combined objects of any African descent they liked from their favourite 'Ethno shop'. Mixing African symbols without a deeper knowledge could be considered quite ignorant. On the other hand, do the stage properties have to come from the same place of origin if they are only to symbolise the African continent as such? Holková combined symbols that people could easily decode as 'African' which was sufficient for the production. The only specific connotation that the creator deliberately developed was the link to the Zulu tribes. Besides using the assegai spear, they also made Roth speak in Zulu several times throughout the performance. However, one of the main questions C. M. Billing asked in his keynote was; if the interpretation suggested Othello became a beast or an animal, why did he have to be 'Africanised'? Returning to the play Shylock, I have mentioned earlier, John, the main character questioned whether each theatre production has to satisfy everybody and whether there should be no controversy anymore. He provided some examples of other classic novels and plays in which racism is implied and defended the fact that he as a Jew played Shylock as means of artistic interpretation. Of course, it is necessary to be extremely cautious when using the simple argument 'because it's an artistic interpretation'. In this case, at least for me, the 'Africanisation' of the character and the mixed origin of the costume accessories have not compelled me, and I have not felt the racism being implied against African people in general and rather focused on the cannibalistic connotations that were developed further on in the production.

The second half of the Brno Othello began with an enormous projection of his face with tribal facial painting as if preparing for a fight. The projection strengthened the dark atmosphere for the scene of the interrogation of Desdemona and the harsh insults she received from her husband. The projection showed Othello preparing for a fight as he was drawing black lines on his face in a ritual manner. Desdemona had also been changing her costumes as her inner emotional world was changing. She began as a 'naughty girl' dressed in her husband's shirt, evoking a precedent sexual intercourse, which was presented at the back of the stage and could have been spotted by an attentive spectator. When defending her relationship with Othello before her father, she came forward casually holding a weapon on her shoulders. The shirt made her vulnerable (for her husband), but the weapon made her also potent (against her father). She had 'a divided duty' to her father and her husband. Her father was portrayed as a foolish old man losing control over his daughter. Holková helped to emphasise that characteristic and made him wear striped pyjamas with a red bathrobe. Desdemona even wore the decorated uniform of her husband when she thought she could persuade him to employ Cassio back. 
Ballek portrayed Desdemona as vulnerable and innocent on the one hand but, on the other hand, he made her emancipated and let her openly flirt with Cassio in a rainbow coloured swimsuit and summer skirt. At the point when Othello was allowing his suspicions to turn him into a predator (in his cheetah shirt) Desdemona changed, on the stage, into a salmon coloured short dress with a plunging neckline that revealed her cleavage and validated the view her husband had that she was a 'whore'. As she rapidly became desperate to the point of losing her mind, her dress became messier, and for a short period when publicly accused of being a 'whore', she wore a black dress symbolising a bit of guilt and shame she was meant to feel. Her almost naked body in a short white dress on a vast empty stage stressed her desperation. The combination of white dress, a white veil and the blackened body of Othello killing her made the murder scene ever more powerful and expressive, juxtaposing the representation of good and evil. At the point when Othello was brutally killing Desdemona, the only costume accessory reminding us of the African connotations was his neckless and the colour of his skin.

Critics highly regarded the production of Othello in Brno especially for the direction as well as for the costumes. However, the issue of racism against black Africans had not been raised to such extent until the Brno Theatralia Conference 2016.

Vladimír Čech, a theatre critic and historian, wrote a review entitled 'Othella zastírá temná čerň. A spousta otázek. [Othello is Covered in Dark Black and a Lot of Questions]', yet he failed to ask the most crucial questions. Instead, he described Othello as 'something between an eruptive frog, a toad, an orangutan, a fearful midget or even humpback Quasimodo' (ČECH 2014: 10). He questioned the fact that, despite the mentions of Othello's Moorish descent his skin was not painted black from the beginning, and he asked whether the painted skin at the end was to reflect Othello's deformed soul, which was the primary purpose in my opinion.

Luboš Mareček, another theatre critic, assessed the issue of the difference between Othello and the rest of the characters in more detail:

The brave Moorish general has been an animalistic creature since the beginning; he has been a tough, savage man as well as additionally whitened Michael Jackson (Roth performed the legendary Moonwalk several times) among the noble white Venetians. He hasn't been blackened into a dignifiedly demystified Moor. This Moor represents another world, another culture and values. Roth indicates his ethnic difference by performing ritual dances with African ritual mask, wooden coral bracelet and neckless or his cheetah T-shirt... He has travelled the world around, and therefore he expresses himself in Czech and Slovak languages as well as in the original Shakespeare language or sometimes even in long forgotten languages of native African tribes. He bears the animal instincts of his ancestors, and maybe that is why he is not able to uncover the deceptive games of his civilised white counterparts. (MAREČEK 2014: 6)

He hasn't been blackened at the beginning, but he performed African ritual dances. He belonged to another world and culture. Was the reviewer afraid to say that the African symbols made Othello a black African man and that all the brutal and animalistic and cruel behaviour, therefore, could be subconsciously assigned to a person of this 
race? He even referred to Othello as unable to understand his civilised white counterparts. Isn't that just a clear racist statement? Is Ballek's interpretation of Othello racist? If not, and we accept the argument of Othello becoming an evil monster, why couldn't he be painted in red which is also the colour of the devil? Why did he have to be 'Africanised' in so many ways?

On the other hand, were the hints to Michael Jackson to balance out the white person being blackened versus a black person wanting to become a white one? Without getting into more detail about the controversy, and possible medical condition, regarding the skin colour of Michael Jackson, it is a perfectly readable symbol of a black person becoming a white (regarding the skin colour). Was it meant to support the common prejudice and supposition that black people often want to become white in order to be accepted among the western European or North American culture? Or was it yet another detail that emerged naturally during rehearsals and was not meant to be read in wider context? In this case, the intention was not clear.

More specifically, Mareček also tackled the issue of the skin colour of Othello before the murder of Desdemona act:

Othello comes to the stage in tight underwear, and his skin is now all black. Is it an expression of his soul, did he put on the makeup for the ritual murder? Or has the unimportant assigned pigment simply appeared before the brutal act that had been preceded by rape and that was crowned by blood bursting out from the mouth of this monster brought to the extreme? (MAREČEK 2014: 6)

Shakespeare's Othello provides an excellent platform to discuss the issues and, whether it is in relation to the racism against Roma people, Muslims or other people of colour, we should use the play and try to resolve the prejudice that has been passed on to us from our parents and their parents before we pass the same sets of bias on to our children. My conclusion is therefore not about the productions, but instead about the courage and sensitivity of the recipients. Are we not seeing the "negatively constructed vision of blackness that was accompanied by increasingly violent and sexually predatory behaviour' (BILLING 2016)? Was it necessary that a British scholar had to come and tell us this fact? How come the reviewers talked about race and the issues connected to racism with such ambivalence, ignorance or shallowness? In the time of African countries being addressed as 'shithole countries' by the President of the United States, the Slovak and Hungarian Prime Ministers openly refusing Muslim immigrants and the everlasting Roma Question, it is important to address the issue of racism openly and properly. Mark Leiren-Young's Shylock was also introduced to the Czech audience, ${ }^{5}$ interpreted by Milan Kňažko, a Slovak actor who was actively involved in politics, even as Minister of culture (1998-2002) and a Presidential candidate in 2014. His monologue is tackling the responsibilities of the artists with regards to racism

5 Mark Leiner-Young: Shylock, Divadlo na Jezerce, 28. 4. 2016, Stage and costume design: Jan Štěpánek, direction: Radek Balaš. For more information see: http://www.divadlonajezerce.cz/divadelni-hra-54-shylockmark-leiren-young 
and antisemitism, and his former political affiliation helps him to deliver the moral of the play even more. 'Should theatre exist to make people comfortable?' - one of the repeated questions that John, the main character of Mark Leiren-Young's Shylock, asks throughout the play, could also be applied to the productions of Othello. I don't think it should always be comfortable, and in fact, I do appreciate the discussion that C. M.Billing and I were able to initiate at the conference in Brno. I wish the issues of politics and race were more openly criticised and dealt with in both Czech and Slovak media and academic journals.

\section{Bibliography}

BAKOŠOVÁ-HLAVENKOVÁ, Zuzana. 2007. Bielo-čierny jarmok Othello [White and Black-Market Othello]. Monitoring divadiel na Slovensku. Recenzie [online] 2007 [accessed on 14. 1. 2018]. Available online at: http://www.theatre.sk/isrecenzie/112/97/BIELO-CIERNY-JARMOKOTHELLO/?cntnt01origid=97/

BILLING, Christian. M. 2016. Race as Scenography in Jozef Ciller's Set Design and Katarína Holková's Costumes for Rastislav Ballek's Production of Othello at the Národní Divadlo Brno (2014). Key note speech at the Brno Theatralia Conference 2016. Czech E Slovak Scenography for Shakespeare, 8-9 November 2016.

ČECH, Vladimír. 2014. Othella zastírá temná čerň. A spousta otázek [Othello is Covered in Dark Black and a Lot of Questions]. Brněnský denik [online] 100: 1 (2014): 10. Available online at: https://www.denik.cz/divadlo/brnenskeho-othella-zastira-temna-cern-a-spousta-otazek20140429-1r0u.html

DLOUHÝ, Oleg. 2005. Shakespeare len pre školy? [Shakespeare only for Schools?]. Domino fórum 14: 41 (12. 10. 2005): 22.

FRÝBERTOVÁ, Tereza. 2014. Jiný Othello [A Different Othello]. Kulturissimo.cz, [accessed on 1. 5. 2014]. Not available online anymore, cited from a printed version.

LEINER-YOUNG, Mark. 2016. Shylock [online]. Divadlo na Jezerce, (28. 4. 2016) [accessed on 10. 6. 2018]. Available online at: http://www.divadlonajezerce.cz/divadelni-hra-54-shylockmark-leiren-young

MAREČEK, Lubomír. 2014. Cholerický živočich jménem Othello [A Choleric Animal Called Othello]. Divadelni Noviny 11 (27. 5. 2014): 6.

MIŠOVIC, Karol. 2016. Musí byt dnešný Othello moslim? [Does Contemporary Othello Have to be Muslim?]. Pravda (22. 9. 2016) [accessed on 14. 1. 2018]. Available online at: https:// kultura.pravda.sk/divadlo/clanok/405657-recenzia-musi-byt-dnesny-othello-moslim/

POLÁK, Milan. 2010. Othello v bermudách a strakatej košeli [Othello in Shorts and a Colourful Shirt.] Literárny (dvoj)týždennik 23: 7-8 (24. 2. 2010): 13.

Shylock: A Play. Biz Books [online]. (C) 2016 [accessed on 12. 6. 2018]. Available online at: http:// store.bizbooks.net/shylockaplay.aspx

ŠPINAR, Daniel. 2014. Špinar: Othello? S jeho obsazením to mají čeští režiséři těžké [Špinar: Othello? Casting of Othello Is Often Difficult for Czech Directors]. Denik.cz [online] (18. 12. 2014) [accessed on 14. 1. 2018]. Available online at: https://www.denik.cz/divadlo/spinarothello-s-jeho-obsazenim-to-maji-cesti-reziseri-tezke-20141218.html 